\title{
A petevezeték-átjárhatóság vizsgálómódszereinek összehasonlító elemzése
}

\author{
Lőrincz Judit dr. ${ }^{1}$ - Jakab Attila dr. ${ }^{2}$ - Török Péter dr. ${ }^{2}$ \\ ${ }^{1}$ Kenézy Gyula Kórház és Rendelőintézet, Szülészeti és Nőgyógyászati Osztály, Debrecen \\ ${ }^{2}$ Debreceni Egyetem, Általános Orvostudományi Kar, Szülészeti és Nőgyógyászati Intézet, Debrecen
}

\begin{abstract}
Az infertilitás leggyakoribb és egyértelmú organikus oka a petevezetékek lezártsága. Az átjárhatóság vizsgálatára már számos módszer áll rendelkezésünkre. A hiszteroszalpingográfia kontrasztanyagos röntgeneljárás, amely a méhüreg alaki rendellenességeit és a petevezetékek lefutását mutatja, azonban sugárterheléssel jár, és nem ad információt egyéb kismedencei eltérésekről. A szono-hiszteroszalpingográfiával hasonló érzékenységgel és fajlagossággal vizsgálhatjuk a méh üregét és a petevezetékek átjárhatóságát ultrahang segítségével, egyúttal a kismedencei képletek vizsgálatára is lehetőségünk van. A transvaginalis hidrolaparoszkópia egy új, minimálisan invazív vizsgálómódszer, amely során a hüvely hátsó boltozatán keresztül bevezetett endoszkóp segítségével a petevezetékek és petefészkek direkt vizsgálatára van mód. A laparoszkópos kromopertubáció a meddőségi kivizsgálás „gold standard”-ja, amely invazivitással és altatással jár, valamint az ellátó intézményt is jobban terheli. Biztonságos és költséghatékony átjárhatósági vizsgálat az office hiszteroszkópia során végzett szelektív pertubáció. Az ambulanter elvégezhető átjárhatósági vizsgálatok negatív prediktív értéke magas, így ezek a meddőségi kivizsgálás első vonalában választásra javasolt módszerek. Orv. Hetil., 2017, 158(9), 324-330.
\end{abstract}

Kulcsszavak: infertilitás, petevezeték-átjárhatóság, hiszteroszalpingográfia, szono-hiszteroszalpingográfia, hidrolaparoszkópia, laparoszkópia, hiszteroszkópia

\section{Comparison of current methods of tubal patency assessment}

\begin{abstract}
Most common organic cause of infertility is the blockage of the Fallopian tubes. Several methods were introduced to evaluate tubal patency. Hysterosalpingography is a conventional radiology procedure using contrast medium, which gives an accurate image of the uterine cavity and the Fallopian tubes, but radiation exposure is necessary. Hysterocontrast-sonography similarly examines the uterine cavity and tubal patency by ultrasonography, and it enables to detect pelvic pathology, too. Transvaginal hydrolaparoscopy is a minimal invasive direct method using endoscope introduced into the abdominal cavity through the posterior vaginal fornix, both ovaries and tubal patency can be observed. Laparoscopy is the "gold standard" procedure in the tubal testing, however it is a more invasive procedure. A cost-effective testing method is the selective tubal pertubation performed via office hysteroscopy. Recent outpatient methods to detect tubal patency have high negative predictive values and recommended to be the first choice in infertility work-up.
\end{abstract}

Keywords: infertility, tubal patency, hysterosalpingography, hystero-contrast-sonography, hydrolaparoscopcy, laparoscopy, hysteroscopy

Lörincz, J., Jakab, A., Török, P. [Comparison of current methods of tubal patency assessment]. Orv. Hetil., 2017, 158(9), 324-330.

(Beérkezett: 2016. október 31.; elfogadva: 2016. december 20.)

\section{Rövidítések}

Ch = Charriere; CHT = kromohidrotubáció; HSG = hiszteroszalpingográfia; $\mathrm{HyCoSy}=$ hystero-contrast-sonography; ICSI = intracitoplazmatikus spermiuminjekció; IVF = in vitro fertilizáció; LSC-CHT = laparoszkópos kromohidrotubáció;
OHSC-SPT = office hiszteroszkópia-szelektív pertubáció; SHSG = szono-hiszteroszalpingográfia; SIS = saline infusion sonography; STD = szexuális úton terjedő nemi betegségek; TVHL $=$ transvaginalis hidrolaparoszkópia 
Világszerte a párok több mint 10\%-a szenved infertilitástól [1], statisztikai adatok szerint hazánkban a házaspárok mintegy 18\%-a szembesül a terhesség vállalásának nehézségével. Míg a női termékenység és a születésszám az egyszerú reprodukciós szint alatt stagnál, lényegesen változott a gyermeket vállaló anyák és a szülőképes korú nők demográfiai összetétele [2]. Az első gyermek szülésére vállalkozók átlagéletkora emelkedik, 2014-ben Magyarországon 28,2 év volt [3]. Az infertilitás jelentős egészségpolitikai kérdéssé vált, hiszen a kivizsgálás és a terápia számottevő anyagi terhet jelent mind a beteg, mind az egészségbiztosítási rendszer szempontjából.

Az infertilis párok számának növekedésének oka multifaktoriális, körülbelül 40\%-ban női, 40\%-ban férfi, 20\%ban pedig közös okokra vezethető vissza [4]. A női eredetű meddőség oka lehet organikus és funkcionális eredetû. A kivizsgálás menete szerteágazó és hosszadalmassá is válhat, amelynek során szükség lehet a nőgyógyász szakorvos mellett urológussal, pszichológussal, endokrinológussal történő konzultációra is, mivel a gyermektelenség hátterében szexuális diszfunkció, genetikai ok, immunológiai ok, krónikus betegség, anatómiai és fejlődési rendellenesség egyaránt állhat.

A meddőség okai többnyire felderíthetők és nagyrészt eredményesen kezelhetők. Az asszisztált reprodukciós technikák fejlődése, különös tekintettel az in vitro fertilizációra (IVF), sok párnak jelentenek megoldást. Női oldalról az IVF elsődleges indikációja és egyben az infertilitás leggyakoribb és definitív oka a petevezetékek lezártsága.

Petevezeték-eredetű infertilitásról beszélünk mindkét kürt hiánya vagy elzáródása esetén. Átjárhatósági vizsgálat pozitív eredményének birtokában, vagyis ha mindkét oldali kürt lezártsága igazolódik, megoldásként az IVF mellett lehetőségként felmerül a kürtök újra átjárhatóvá tétele (rekonstrukciós reproduktív sebészet). Az operatív beavatkozások eredményessége azonban nem haladja meg az IVF sikerességét, ráadásul nagyobb megterheléssel járnak. Az IVF javallata azonban nagy felelősséggel is jár, tekintettel az ICSI-vel fogant terhességek perinatalis jellemzőire, és az újszülöttek hosszabb távú egészségére. Ezért kiemelten fontos, hogy a petevezeték átjárhatóságára vonatkozó vizsgálatok az elvárható pontossággal és hozzáértéssel történjenek, csökkentve az álpozitív eredményeket.

Jelen közlemény célja gyakorlatias szempontok mentén áttekinteni a petevezetékek átjárhatóságának vizsgálatára napjainkban alkalmazott módszereket, összehasonlítani azok diagnosztikus teljesítőképességét, valamint előnyeiket és hátrányaikat.

\section{Anatómiai és élettani áttekintés}

Gabriele Fallopius elsőként írta le 1561-ben a petevezetéket és annak különböző szakaszait, valamint hasonlította más emlősök petevezetékeihez [5].
A páros petevezeték (Fallop-csatorna, tuba uterina, salpinx) a Müller-cső származéka. Mintegy 10-12 cm hosszúságú mobilis hasúri seromuscularis szerv, amelyet funkcionális szempontból méhen belüli (intramuralis), szúkebb isthmicus és tágabb infundibularis, ampullaris szakaszra tagolunk. A petesejt megtermékenyülése rendszerint az ampulla distalis szakaszában történik, innen az embrió proximális irányba halad a csillós hámsejtek és a nyálkahártya alatt fekvő, jól fejlett izomréteg perisztaltikus mozgása révén. A méhkürt nyálkahártyáján a nyákréteg a méhüreg irányába folyamatos áramlásban van. Ez, valamint a petevezeték falában lévő simaizomrétegek perisztaltikus összehúzódásai biztosítják a kiszabadult petesejt vándorlását a méh ürege felé. Az áramlás irányítja a spermiumok mozgását, amelyek aktív ostoros mozgással, az áramlással szemben haladva jutnak fel a petevezetéken. A nyákréteg áramlásának barrier funkciója is van, megakadályozza a kórokozók aszcendáló terjedését. Az izomréteg simaizomból áll, amely egy vastag belső körkörös, egy középső körkörös és egy vékonyabb külső hosszanti réteget képez. Az izomszövet mennyisége az ampulla felé haladva csökken. A simaizom biztosítja a petevezetéknek a méh irányába futó tovahaladó összehúzódásait. Az anatómiai és hisztopatológiai képletek ismerete elengedhetetlen a petevezetékek és a méh üregének vizsgálatához, amelyre egyre biztonságosabb és hatékonyabb vizsgálómódszerek állnak rendelkezésünkre.

\section{Átjárhatósági vizsgálatok}

William Tyler Smith már 1849-ben feltételezte, hogy a meddőség oka a petevezetékek elzáródása lehet, és ennek megoldására tapintás útján, hüvelyen keresztül felvezetett egy J alakú ezüstkanült, amelyen át egy bálnacsont tûvel igyekezett az elzáródást megszüntetni [6].

A napjainkban használatos eljárások során a méhnyakon keresztül kontrasztanyagot juttatunk a méh üregébe, majd a kürtökbe kerülő anyagot valamely képalkotó módszer segítségével vizualizáljuk és véleményt alkotunk a tubák állapotáról. Az átjárhatósági vizsgálatokat két nagy csoportra oszthatjuk: direkt és indirekt módszerekre.

\section{Indirekt módszerek}

Indirekt módszerek a következők lehetnek:

- röntgenképalkotással végzett hiszteroszalpingográfia (HSG),

- ultrahangos képalkotással végzett hiszteroszalpingográfia (SHSG) gyári kontrasztoldattal (hystero-contrast-salpingography - HyCoSy) vagy fiziológiás sóoldattal (saline infusion sonography - SIS). 


\section{Direkt módszerek}

Direkt módszerek a következők lehetnek:

- hastükrözéses petevezeték-átjárhatósági vizsgálat, laparoszkópos kromohidrotubáció (LSC-CHT),

- transvaginalis hidrolaparoszkópia (TVHL),

- office hiszteroszkópia-szelektív pertubáció (OHSCSPT).

\section{Hiszteroszalpingográfia}

A hiszteroszalpingográfia egy röntgenkontrasztanyagos eljárás, amely a méhüreg alaki rendellenességeiről és a petevezetékek állapotáról pontos képet ad.

1909-ben Novenov volt az első, aki Lugol oldatot használt a tubák kirajzolására. Rindfleish bizmutemulziót próbált 1910-ben, 1922-ben Sicard Fureshier kezdte el a Lipidolt használni, amely $40 \%$ jódot tartalmazott mákolajjal elkeverve. A vízoldékony médiát csak 1950 után kezdték alkalmazni, mivel észlelték, hogy a korábbi hiperozmoláris oldatok mind a beavatkozás közben, mind pedig utána nagy fájdalmat váltanak ki [7].

A HSG-vizsgálat ultrarövid anesztéziában végezhető A hüvelyi tükör elhelyezése után $10-20 \mathrm{ml}$ vízoldékony jódos kontrasztanyagot juttattunk fokozatosan az uterusba. Ehhez korábban merev Schultze-eszközt használtunk, újabban vékony, ballonos Foley-katétert alkalmazunk. Normális viszonyok mellett telődik az uterus, és az egészséges tubákon átjutva gyorsan megjelenik a kontrasztanyag a szabad hasüregben is. A vizsgálatot átvilágítóberendezés használatával, szem ellenőrzése mellett végezzük, és anteroposterior irányú felvételeket készítünk (1. ábra). A vizsgálat során az ovariumot ért irradiáció mértéke 10 mGy körül van, ami elfogadható érték. Annak ellenére, hogy a megtermékenyített petesejt radioszenzitív, a megtermékenyítés előtt álló ovum relatíve radiorezisztens [8].

Szövődményekre a HSG-vizsgálatok 1\%-ában számíthatunk, amelyek lehetnek fájdalom, allergiás reakciók, vénás intravasatio, vérzés vagy uterusperforáció [9].

Ma a hiszteroszalpingográfia az infertilitás kivizsgálása során még sok helyen rutinszerúen végzett eljárás. Ellenjavallatai a kismedencei gyulladás, szepszis, STD, súlyos vese- és szívelégtelenség, kontrasztanyag-allergia, nem régen végzett tubatágítás és kürettázs, terhesség. A vizsgálat optimális időpontja a ciklus 6 . és 12. napja között van [1]. Sokszor terápiás következménye is van úgynevezett „tubal flushing” hatás révén: a kontrasztanyaggal történő átfecskendezés szabaddá teheti a petevezeték üregrendszerét [10]. A módszer hátránya, hogy nem ad információt a kismedencei viszonyokról, anesztéziát igényel, valamint csekély mértékủ röntgensugár-terheléssel jár. Hét tanulmány metaanalízise alapján, amely során 4521 nő vizsgálatát elemezték, a gold standardnak számító laparoszkópiához hasonlítva a módszer specificitása $86 \%$, szenzitivitása $53 \%$ valamelyik tubát érintő elváltozás detektálására [1]. Egy másik feldolgozásban a HSG specificitása $83 \%$, szenzitivitása $65 \%$ a kürtök átjárhatóságára vonatkozóan [11].

\section{Hisztero-kontraszt-szalpingográfia}

1989-ben Deichert és Schlief használt először kontrasztanyaggal erősített transvaginalis ultrahangvizsgálatot a petevezeték átjárhatóságának megítélésére [12]. A hisztero-kontraszt-szalpingográfia (hystero-contrast-sonography - HyCoSy) eljárással viszonylag gyorsan és egyszerüen vizsgálhatjuk a méh üregét és a petevezetékek átjárhatóságát. Az eljárás lényege, hogy a méh üregébe vezetett vékony katéteren keresztül kontrasztanyagot fecskendezünk be, ultrahangvizsgálattal pedig real-time kapunk képet a méh üregéről, a petevezetékekról és a petefészkekről. A kontrasztanyag az üregból kiürülve halad át a petevezetékeken, így meggyőződhetünk a szabad áramlásról, illetve elakadásának lokalizációjáról (2. ábra). A kontrasztanyag lehet galaktózoldat (például: Echovist, Schering AG, Berlin, Németország) vagy akár steril élettani sóoldat is (saline infusion sonography - SIS). Utóbbi esetben azonban a tubák lefutása ritkán látszik, de a méh körül megjelenő echómentes folyadék igazolja, hogy legalább az egyik petevezeték átjárható. Premedikáció nem szükséges, a vizsgálatot ambulanter végezzük üres hólyag mellett, nőgyógyászati vizsgálóasztalon hüvelyi ultrahangkészülékkel. Először egy áttekintő ultrahangvizsgálattal ellenőrizzük a méh, a cervix, az endometrium, az ovariumok állapotát és helyzetét. A cervix
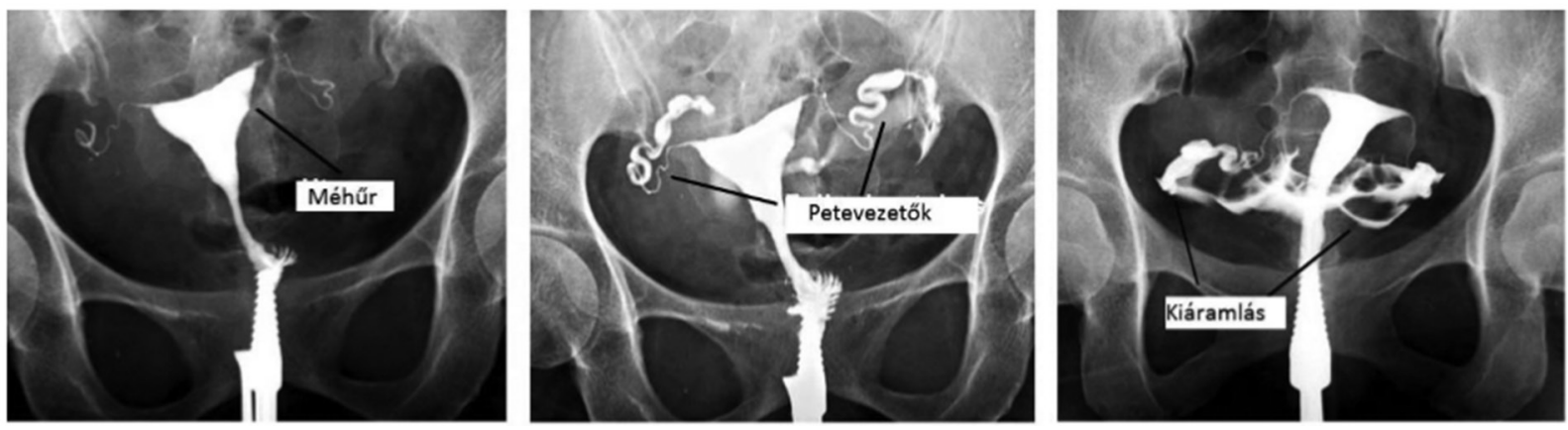

1. ábra

Hiszteroszalpingográfia folyamatában: a méhűr és a petevezetékek kirajzolódása, majd a radio-kontrasztanyag kiáramlása a hasüregbe egy negatív átjárhatósági vizsgálat esetén 

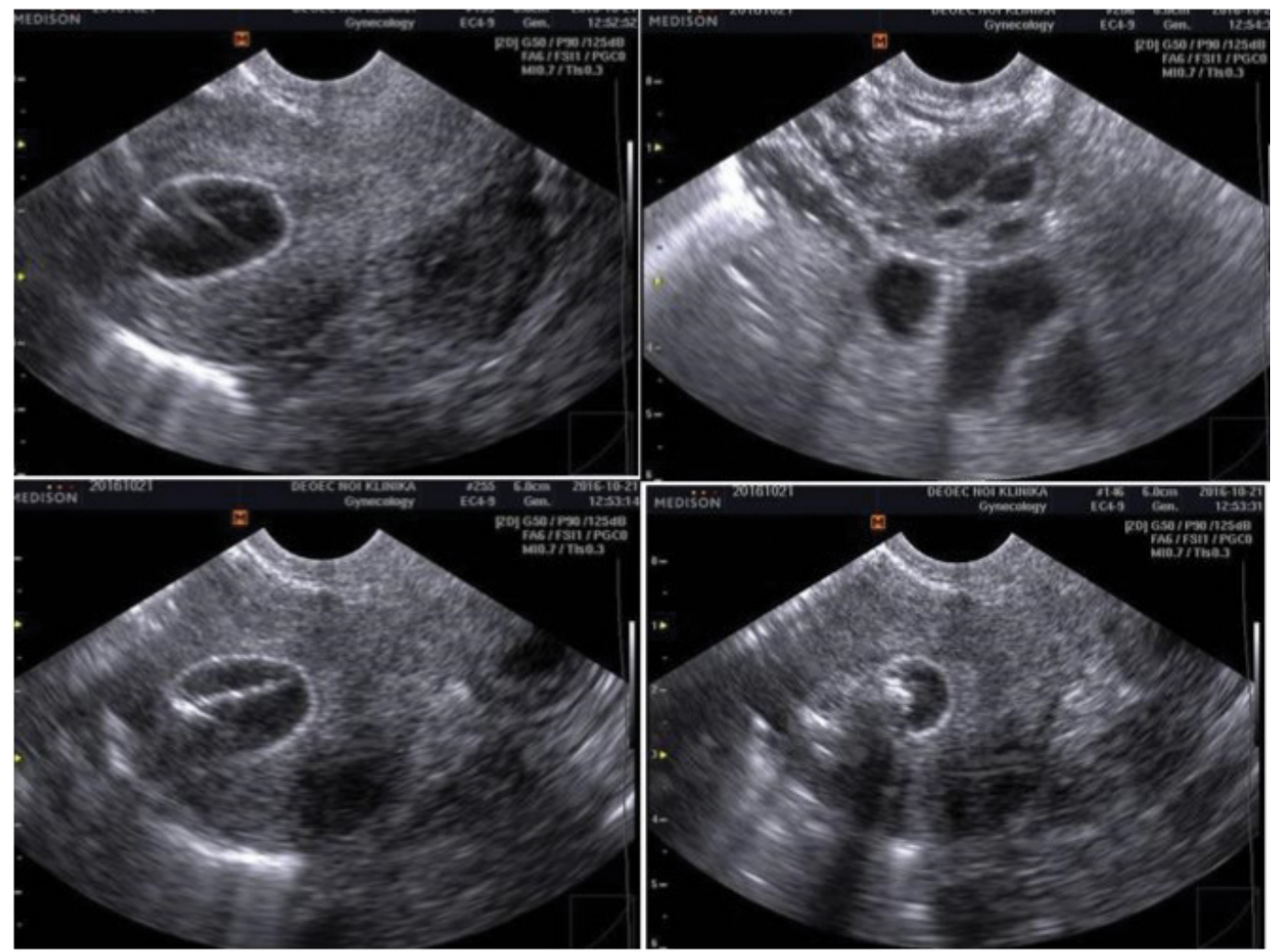

2. ábra

| SHSG: a kontrasztanyag a méh üregéből kiáramolva halad át a petevezetékeken

dezinficiálását követően kis méretű katétert (például 8 Ch ballonos hólyagkatéter) vezetünk a méhüregbe, majd transvaginalis ultrahang-ellenőrzés mellett a katéteren keresztül lassan sóoldatot fecskendezünk a méh üregébe, ezzel disztendálva azt. A kontraszt médium hiperechogén, a sóoldat pedig anechogen megjelenésü. Color, illetve power Doppler-vizsgálattal kombinálva a folyadék lassú áramlása láthatóvá tehető. A vizsgálat optimális ideje a ciklus első fele, a menstruáció utáni 10 napon belül. Bár menstruációs fájdalmakhoz hasonló enyhe alhasi diszkomfort előfordulhat, anesztézia nem szükséges. Ritkán fordul elő erősebb fájdalom, gyorsan múló hányinger, esetleg hányás, vérnyomáscsökkenés. További ritka szövődmény lehet a hashártya irritációja és az ezzel járó görcsös fájdalom is. Az eljárással összefüggésbe hozható hashártyagyulladás azonban gyakorlatilag nem fordul elő [13].

A HSG és az SHSG összevetésekor legtöbb esetben az utóbbi eljárás bizonyul kedvezőbbnek, mivel nem jár sugárterheléssel és ambulanter végezhető. Az SHSG kitünő szenzitivitású és specificitású eljárás a méhứri eltérések, például endometrialis polypusok, submucosus myomák diagnosztikájában is. Ami a petevezeték-átjárhatóságot illeti, olyan infertilis betegek vizsgálata során, akik mind HSG-, mind pedig HyCoSy-vizsgálaton átestek, specificitás és szenzitivás tekintetében a két módszer egyenértékünek bizonyult [14, 15]. Érdekes azonban, hogy a bal oldali átjárhatóság kimutathatósága elmarad a jobb oldaliétól [16].

\section{Laparoszkópia-kromohidrotubáció}

1940-ben egy forradalmian új vizsgálómódszer indult útjára, a culdoscopia, amely elnevezését a Douglas-üreg francia nevéról (cul de sac) kapta [17]. A beavatkozás során a hátsó hüvelyboltozaton keresztül egy fényoptikás eszközt a hasüregbe vezetve lehetőség nyílt a kismedencei szervek, köztük a petevezetékek vizsgálatára is. A culdoscopiából fejlődött ki a nőgyógyászati laparoszkópia, amely ma a nőgyógyászat egyik legfontosabb diagnosztikus és operatív technikája. A hidrolaparoszkópia bevezetésére csak ezután került sor [18].

A laparoszkópos vizsgálat során elvégzett kromopertubáció (LSC-CHT) a petevezeték átjárhatóságát vizsgálja (hiszteroszkópiával kombinálva vagy a nélkül), a meddőségi kivizsgálás „gold standard”-ja. Az eljárás során metilénkék festéket juttatunk a méh üregébe a méhnyakba felhelyezett eszközön keresztül, amely feltölti a méhüreget, majd a petevezetékeket, végül kifolyik a hasüreg felé azok szájadékán. A hasüregben megjelenő kék festék a petevezeték átjárhatóságának biztos jele. Laparoszkópia során egyéb kismedencei elváltozások felismerésére, valamint ezek azonnali megoldására is mód van (3. ábra).

Bár az LSC-CHT nagy pontossága és kiterjedt diagnosztikus lehetőségei által a legmegbízhatóbb diagnosztikus módszernek tekinthető, számolnunk kell az invazivitással, a beteg számára nagyobb egészségügyi terheléssel és kockázatokkal (általános anesztézia, esetleges vas- 


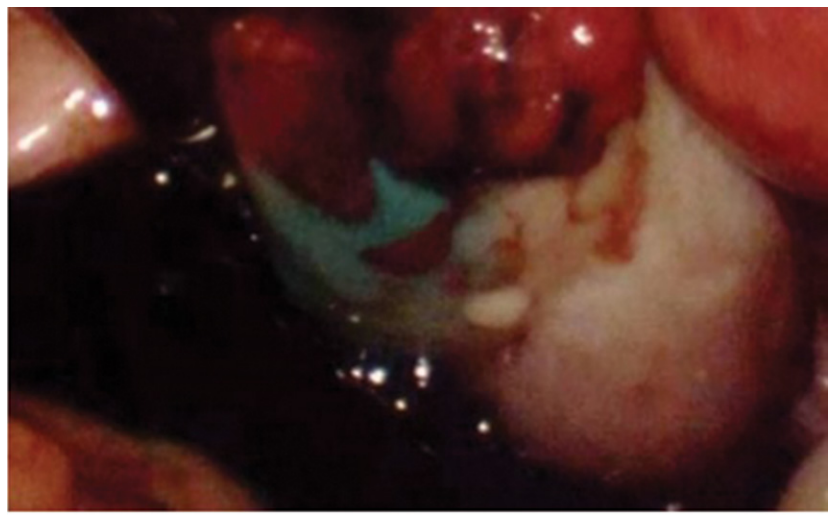

3. ábra $\mid$ Laparoszkópos kromohidrotubáció: a metilénkék festék kiáram lása a fimbrialis végen

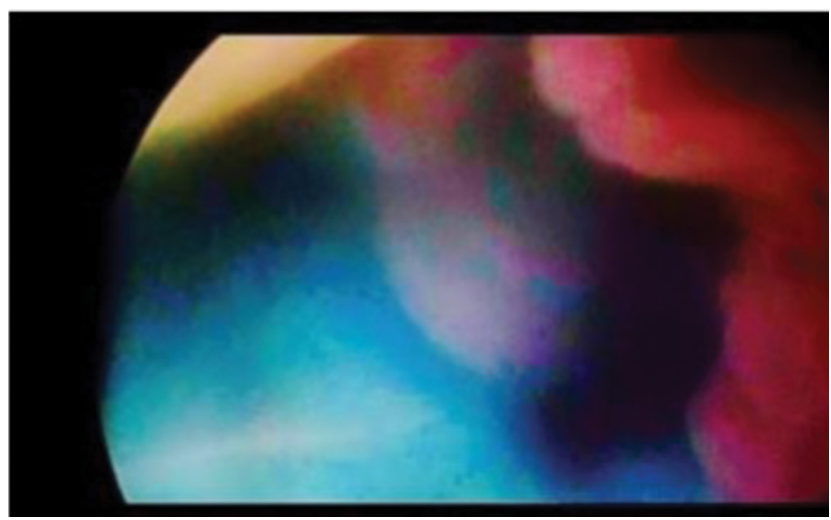

4. ábra $\quad$ Kromohidrotubáció TVHL során

cularis és gastrointestinalis sérülések), ezért egyéb módszerek birtokában önmagában a petevezetékek vizsgálatára egyre ritkábban alkalmazzuk. Előnye azonban, hogy más képalkotó módszerrel nem vagy nem pontosan diagnosztizálható kismedencei kóros állapotok is felismerésre és lehetőség szerint megszüntetésre kerülhetnek. Corson és mtsai tanulmányukban leírták, hogy 100 esetből, ahol a HSG negatív volt és a petevezetékek átjárhatóak voltak, laparoszkópia során 68 esetben találtak váratlan eltérést a kismedencében [19]. Al-Badawi és mtsai közlése szerint negatív HSG-vizsgálatot követően elvégzett laparoszkópia során 49\%-ban volt valamilyen patológiája (endometriosis, adhézió) a páciensnek, bár ezeknek 93\%-a csak enyhe fokú eltérés volt [20].

\section{Transvaginalis hidrolaparoszkópia}

1998-ban Gordts alkalmazta először a transvaginalis hidrolaparoszkópiát Leuvenben, amely a culdoscopia, a laparoszkópia és a hiszteroszkópos eljárás kombinációjából kialakított vizsgálómódszer [20]. A vizsgálat során a hüvely hátsó boltozatán ejtett metszésen a hasüregbe vezetett endoszkóp a kismedencébe juttatott fiziológiás sóoldatba merül, így a petevezetékek és a petefészkek szabadon lebegve figyelhetők meg. A Douglas-üreg, a sacrouterin szalagok, a hátsó latumlemezek, a petefész- kek (amelyek az endometriosis predilekciós helyei) és a petevezetékek kiválóan tanulmányozhatók megfelelő látószögű optikával. Ezenkívül a kromopertubáció is elvégezhető, s a kék festék hasüregi megjelenését szintén meg lehet erősíteni (4. ábra). Az eljárás során sikerült először megfigyelni az ovuláció kapcsán kiszabadult petesejt fimbrialis felvételét a petevezetékbe [21].

A TVHL-mútét helyi érzéstelenítésben történik, a laparoszkópiával ellentétben általános anesztézia nem szükséges. Negatív tapintási lelet és kismedencei ultrahang birtokában az eljárás elvégezhető, amelynek kezdő lépése a diagnosztikus hatékonyság növelését szem előtt tartva, egy diagnosztikus hiszteroszkópia. Az uterus üregébe kis átmérőjü (Ch 8) ballonkatétert vezetünk a kromohidrotubáció érdekében. Ezt követően történik a hüvely hátsó boltozatán ejtett metszésen keresztül egy speciális - transvaginalis endoszkópiára kifejlesztett eszközzel történő behatolás, amely a bélsérülés kockázatát minimalizálja. A kismedencébe jutva azt $300 \mathrm{ml}$ fiziológiás sóoldattal feltöltjük. A TVHL egy gyors, biztonságos és a betegek számára a diagnosztikus laparoszkópiával összehasonlítva kevésbé megterhelő diagnosztikus eljárás [22]. A tubák átjárhatóságának vizsgálatán túl, az eszköztár fejlődésével egyúttal több operatív beavatkozás is elvégezhetővé vált (adhesiolysis, cystapunctio, ovariumdrilling), szintén helyi érzéstelenítésben, ambulanter körülmények között.

\section{Office hiszteroszkópia-szelektív pertubáció}

A videoendoszkópia megjelenése tette lehetővé a hiszteroszkópia térhódítását is az 1990-es években. Újabban az úgynevzett „no-touch” office hiszteroszkópos technika során, vékony optikák használatával már feltárásra, a méhszáj megragadására, szondázására, tágítására sincs szükség. A vizsgálat érzéstelenítés nélkül is, fájdalommentesen elvégezhető.

Hiszteroszkópia során értelemszerúen teljesebb képet kapunk a méh üregéről, mint a HSG- vagy SHSG-vizsgálatoknál. Operatív eszközökkel a felfedezett elváltozások (méhen belüli polypusok, myomák, septum) a „see and treat" elv alapján akár el is távolíthatóak. A kiváló hiszteroszkópos képminőség és a méhen belüli pontos anatómia megfigyelése felvetette a petevezetékekkel kapcsolatos vizsgálódás lehetőségét is.

A tubák átjárhatóságának vizsgálatához munkacsatornával is rendelkező optikai hüvely segítségével egy műanyag katétert vezetünk fel a tubák szájadékához. Mindkét oldalon külön-külön a laparoszkópos kromohidrotubáció során rutinszerűen alkalmazott metilénkék festéket fecskendezünk a kürtökbe. A sóoldattal telített méhüregben jól követhető az átlátszó katéterben megjelenő kék festék. Amennyiben a kürt átjárható, úgy a méh ürege átlátszó marad, de ha a kürt le van zárva, a színezett sóoldat visszafolyik a méh üregébe és kékre színezi azt. A módszer egyik előnye a többi eljáráshoz képest a szelektivitása. Innen ered a neve is: office hiszteroszkópia 
során végzett szelektív pertubáció (OHSC-SPT). A módszer specificitása $100 \%$, szenzitivitása 87,5\% [4] (1. táblázat).

1. táblázat A petevezeték-átjárhatóság vizsgálatára szolgáló módszerek diagnosztikus teljesítménye (legalább az egyik tuba átjárhatóságá ra vonatkozóan)

\begin{tabular}{lcc}
\hline & Szenzitivitás & Specificitás \\
\hline HSG & $\sim 60 \%$ & $\sim 80 \%$ \\
SHSG & $\sim 70 \%$ & $\sim 80 \%$ \\
LSC-CHT & $\sim 100 \%$ & $\sim 100 \%$ \\
TVHL-CHT & $92 \%$ & $100 \%$ \\
OHSC-SPT & $87,5 \%$ & $100 \%$ \\
\hline
\end{tabular}

2. táblázat |A petevezeték-átjárhatóság vizsgálatára szolgáló módszerek gyakorlati jellemzői

\begin{tabular}{|c|c|c|c|c|}
\hline & $\begin{array}{l}\text { Intézeti } \\
\text { háttér }\end{array}$ & Anesztézia & $\begin{array}{l}\text { Diagnosztikus } \\
\text { többlet- } \\
\text { információ }\end{array}$ & Költség \\
\hline HSG & Egynapos & IVA & Méhüreg & + \\
\hline SHSG & Ambulanter & - & $\begin{array}{l}\text { Méhüreg, } \\
\text { petefészek }\end{array}$ & + \\
\hline LSC-CHT & Egynapos & ITN & $\begin{array}{l}\text { Petefészek, } \\
\text { hasüreg }\end{array}$ & +++ \\
\hline TVHL-CHT & Ambulanter & - & $\begin{array}{l}\text { Méhüreg, } \\
\text { kismedence }\end{array}$ & ++ \\
\hline OHSC-SPT & Ambulanter & - & Méhüreg & ++ \\
\hline
\end{tabular}

ITN = intratrachealis narkózis; IVA = intravénás anesztézia

\section{Megbeszélés}

A tuba uterinák átjárhatóságának vizsgálata kiemelkedő fontosságú szerepet tölt be az infertilitás kivizsgálásában. A meddő párok számának emelkedésével és az asszisztált reprodukciós technikák terjedésével az ambulanter végezhető költséghatékonyabb és kisebb terhelést jelentő diagnosztikus módszerekre is egyre nagyobb az igény.

A jelenleg rendelkezésre álló kürtátjárhatósági vizsgálómódszerek közül a hiszteroszalpingográfia a legrégebbi módszer. Jó diagnosztikai mutatói ellenére sugárterhelést jelent a beteg számára. Az ultrahang-ábrázolást alkalmazó, ambulanter végezhető kontrasztanyaggal erősített SHSG (HyCoSy) diagnosztikai pontossága megegyezik a HSG-jével. Mindkét módszer jónak bizonyul a petevezetékek esetleges elváltozásainak detektálásában, de a HSG nem ad információt a kismedencei viszonyokról, amelyekról SHSG során azonban tájékozódhatunk. Bár az LSC-CHT kiterjedt diagnosztikus és egyben terápiás lehetőségekkel bír, számolnunk kell az invazivitással, és nagyobb anyagi megterhelést jelent az ellátó intézmény számára is. Az office hiszteroszkópia biztonsággal alkalmazható az infertilitás kivizsgálásában.
A közelmúltban kifejlesztett egyedi módszer, a szelektív pertubáció lehetővé tette, hogy a kürtöket külön-külön is vizsgálhassuk az ambuláns átjárhatósági vizsgálat során.

\section{Következtetés}

Elmondható, hogy a HyCoSy és OHSC-SPT magas szenzitivitású, olcsó és egyszerúen kivitelezhető módszerek, amennyiben a tárgyi és a személyi feltételek is adottak, azaz a megfelelő eszközparkkal és kellő gyakorlattal rendelkezik a vizsgálatot végző orvos.

Ezen ambulanter elvégezhető kürtátjárhatósági vizsgálatok negatív prediktív értéke magas, így első lépcsőben javasolható vizsgálatok az infertilitás kivizsgálásakor. A petevezetékek átjárhatóságának ellenőrzésére alkalmas korszerû ambulanter, érzéstelenítést nem igénylő vizsgálatok terjedésével a diagnosztikus laparoszkópiák száma csökkenthető, illetve pozitív lelet birtokában végzendő, második lépcsős vizsgálattá tehető (2. táblázat).

A petevezeték a megtermékenyülésben aktív szerepet játszó szerv, amelynek sajátos simaizom-múködése, szimpatikus és paraszimpatikus beidegzése, valamint hormonreceptorai vannak. A lezárt petevezeték oka sokszor nem magyarázható, akár átmeneti állapot is elképzelhető. A petevezeték élettani múködésének jobb megismerése a vizsgálóeljárások további fejlődéséhez vezethet. A meddőség okainak újabb aspektusait feltárva, a minimálisan invazív vizsgálati módszerek továbbgondolhatók, új technikák fejleszthetők ki.

Anyagi támogatás: A közlemény megírása, illetve a kapcsolódó kutatómunka anyagi támogatásban nem részesült.

Szerzői munkamegosztás: L. J.: Irodalomkutatás, a kézirat megírása. J. A.: A kézirat szerkesztése. T. P.: Irodalomkutatás, a kézirat szerkesztése. A cikk végleges változatát valamennyi szerző elolvasta és jóváhagyta.

Érdekeltségek: A szerzőknek nincsenek érdekeltségeik.

\section{Irodalom}

[1] Broeze, K. A., Opmeer, B. C., van der Veen, F., et al.: Individual patient data meta-analysis: a promising approach for evidence synthesis in reproductive medicine. Hum. Reprod. Update, 2010, 16(6), 561-567.

[2] Hungarian Central Satistical Office: Statistical Mirror. [Központi Statisztikai Hivatal: Statisztikai Tükör, 2014/126. [Hungarian]

[3] Kapitány, B., Spéder, Zs.: Child desire. In: Monostori, J., Öri, P., Spéder, Zs. (eds.): Demographic portrait of Hungary. [Gyermekvállalás. In: Őri, P., Spéder, Zs. (szerk.): Demográfiai portré.] Központi Statisztikai Hivatal, Népességtudományi Kutatóintézet, Budapsest, 2015, 41-56.

[4] Török, P.: Application of office hysteroscopy in gynaecological practice. PhD thesis. University of Debrecen, 2014.

[5] Herrlinger, R., Feiner, E.: Why did Vesalius not discover the Fallopian tubes? Med. Hist., 1964, 8(4), 335-341. 
[6] Smith, W. T.: On a new method of treating sterility by the removal of obstructions of the Fallopian tubes. Lancet, 1849, 53(1342), 529-531.

[7] Eisenberg, R.: Obstetrical and gynecologyc radiology. Radiology, an illustrated history. Mosby, St Louis, 1992, 347-363.

[8] Hedgpeth, P. L., Thurmond, A. S., Fry, R., et al.: Radiographic fallopian tube recanalization: absorbed ovarian radiation dose. Radiology, 1991, 180(1), 121-122.

[9] Sowa, M., Shimamoto, T., Nakano, R., et al.: Diagnosis and treatment of proximal tubal obstruction by fluoroscopic transcervical Fallopian tube catheterization. Hum. Reprod., 1993, 8(10), 1711-1714

[10] Mohiyiddeen, L., Hardiman, A., Fitzgerald, C., et al.: Tubal flushing for subfertility. Cochrane Database Syst. Rev., 2015, (5), CD003718.

[11] Swart, P., Mol, B. W., van der Veen, F., et al.: The accuracy of hysterosalpingography in the diagnosis of tubal pathology: a meta-analysis. Fertil. Steril., 1995, 64(3), 486-491.

[12] Deichert, U., Schlief, R., Van de Sandt, M., et al.: Transvaginal hysterosalpingo-contrast-sonography (Hy-Co-Sy) compared with conventional tubal diagnostics. Hum. Reprod, 1989, 4(4), 418-424.

[13] Savelli, L., Pollastri, P., Guerrini, M., et al.: Tolerability, side effects, and complications of hysterosalpingocontrast sonography (Hy-Co-Sy). Fertil. Steril., 2009, 92(4), 1481-1486.

[14] Luciano, D. E., Exacoustos, C., Johns, D. A., et al.: Can hysterosalpingi-contrast sonography replace hysterosalpingography in confirming tubal blockage after hysteroscopic sterilization and in the evaluation of the uterus and tubes in infertile patients? Am. J. Obstet. Gynecol., 2011, 204(1), 79.el-79.e5.

[15] Lim, C. P., Hasafa, Z., Bhattachrya, S., et al.: Should a hysterosalpingogram be a first-line investigation to diagnose female tubal subfertility in the modern subfertility workup. Hum. Reprod., 2011, 26(5), 967-971.

[16] Guerriero, S., Ajossa, S., Lai, M. P., et al.: Transvaginal ultra sonography associated with colour Doppler energy in the diagnosis of hydrosalpinx. Hum. Reprod., 2000, 15(7), 1568-1572

[17] Decker, A., Cherry, T. H.: Culdoscopy: a new method in the diagnosis of pelvic disease. Am. J. Surg., 1944, 64(1), 40-44.

[18] Morócz, K.: Endoscopy in gynecology. In: Fekete, S. (ed.): De velopments in obstetrics and gynecology. $[\mathrm{Az}$ endoszkópia a nőgyógyászatban. In: Fekete, S. (szerk.): A szülészet és nőgyógyászat haladása.] Medicina Könyvkiadó, Budapest, 1962, 630-643

[19] Corson, S. L., Cheng, A., Gutmann, J. N.: Laparoscopy in the "normal" infertile patient: a question revisited. J. Am. Assoc. Gynecol. Laparosc., 2000, 7(3), 317-324.

[20] Al-Badawi, I. A., Fluker, M. R., Bebbington, M. W.: Diagnostic laparoscopy in infertile women with normal hysterosalpingograms. J. Reprod. Med., 1999, 44(11), 953-957.

[21] Gordts, S., Campo, R., Rombauts, L., et al.: Transvaginal hydrolaparoscopy as an outpatient procedure for infertility investigation. Hum. Reprod., 1998, 13(1), 99-103.

[22] Lampé, R., Pozsgay, A., Török, P., et al.: Transvaginal hydrolaparoscopy: Literature review and our initial results. [Transzvaginális hydrolaparoscopia: irodalmi áttekintés és kezdeti eredményeink.] Magyar Nőorv. L., 2014, 77, Különszám, 102. [Hungarian]

(Lőrincz Judit dr., Debrecen, Bartók Béla út 2-26., 4031 e-mail: ju.lorincz@gmail.com)

\section{Pályázati felhívás}

Professzor Dr. Fehér János munkássága, szakmai és erkölcsi hagyatéka páratlan és maradandó az orvostudományban. Ezért a Semmelweis Egyetem Általános Orvostudományi Kar II. sz. Belgyógyászati Klinika volt igazgatója, „A hepatológiai szabad gyökös és immunológiai vonatkozásai" címü program vezetöjének, az Orvosi Hetilap föszerkesztöjének emlékére Alapítvány létesült. Az alapítványt a Fővárosi Bíróság 2011. március 7-én 11.335. sorszám alatt nyilvántartásba vette.

Dr. Fehér János Emlékére Alapítvány fő célja: a belgyógyászat, különösen a hepatológia szabad gyökös és immunológiai vonatkozásai témakörök kutatásának fejlesztése, támogatása, illetve ösztönzése oly módon, hogy a fiatal egyetemi oktatók és hallgatók az alapitvány kamatából részesüljenek. Az alapitvány célja olyan orvosok, PhD-hallgatók dijazása, akik kiemelkedö tudományos munkát végeznek és eredményeiket az Orvosi Hetilapban publikálják.

A dolgozatot „Dr. Fehér János pályázat” megjelölésével kell benyújtani.

A pályázatot 2017. április 5-ig lehet beküldeni a Kuratórium elnökének (Dr. Rácz Károly) vagy titkárának (Dr. Lengyel Gabriella) - Semmelweis Egyetem, II. sz. Belgyógyászati Klinika, 1088 Budapest, Szentkirályi u. 46. címre.

A pályázathoz mellékelni kell a pályázó önéletrajzát és a dolgozatot.

A dijak odaítéléséről a kuratórium dönt. A dij átadására a Markusovszky ünnepségen kerül sor. Az ünnepségen a nyertes pályázó maximum 5-10 perces elöadásban foglalja össze az eredményeit. 